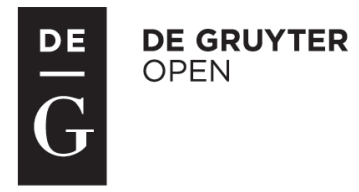

\title{
CAPON PRODUCTION - BREEDING STOCK, ROOSTER CASTRATION AND REARING METHODS, AND MEAT QUALITY - A REVIEW
}

\author{
Jolanta Calik \\ Department of Animal Genetic Resources Conservation, \\ National Research Institute of Animal Production, 32-083 Balice n. Kraków, Poland \\ Corresponding author: jolanta.calik@izoo.krakow.pl
}

\begin{abstract}
Over the last decade, there has been an increased consumer interest in niche food products with special aroma and flavour, and rich in nutrients. Poland has a large (19 lines) and valuable collection of laying hens enrolled in the genetic resources conservation programme. Research to date has shown these hen breeds to vary in phenotype, productivity, and biological quality of hatching eggs and meat. A significant problem in using hens for both egg and meat production is that the number of unwanted cockerels increases with increasing intensity of egg production. This problem can be overcome by castration of cockerels. Roosters were sterilized long before Christ, first as a religious ritual and then to increase the body weight of birds. The qualities of capon meat were noticed much later when it turned out to be more delicate, juicy and tender compared to rooster meat. The aim of this paper was to review the literature on capon production, including the effects of castration on the bird's body and on the quality of meat obtained.
\end{abstract}

Key words: capon, castration, rearing methods, meat quality

Over the past several decades, poultry farming has grown from small-scale production to a specialized segment of animal production that is effective and flexible in responding to consumer demand. Many years of intensive selection resulted in considerable progress in production traits of poultry. During the last 30 years, slaughter weight of broiler chickens has doubled while the rearing period was almost halved (Gilewski et al., 2010). These successes are due to application of achievements in population genetics as well as broadly defined animal and veterinary sciences, notably those concerning the improvement of avian housing conditions, nutrition, lighting and prophylaxis. However, progress in increasing growth rate has many negative consequences such as excessive fatness, deterioration in meat quality, and conformation defects due to uneven development of the organs (Świerczewska et al., 2002; Debut et al., 2007). Increased incidence of sudden death syndrome (SDS) and ascites has also been observed. Other problems of significance include sternal bruis- 
ing (breast blisters), and deformation of legs: femoral degeneration (FD) and tibial dyschondroplasia (TD). The taste and nutritional quality of meat from fast-growing birds was also found to deteriorate. According to Berri et al. (2005), a high growth rate, a rapid increase in muscle mass and the intensive production system of these chickens are often the reason for a deterioration of meat quality as a result of metabolic disturbances in muscle cells.

The increasing importance attributed to the quality of food products on the world market has raised the quality requirements for poultry meat. In recent years, there has been an increased consumer interest in niche food products with special aroma and flavour, and rich in nutrients. Consumers show a growing interest in broiler chicken products obtained from native breeds managed under semi-intensive or extensive conditions and are willing to pay for higher quality products with specific sensory characteristics. A great success in this area has been achieved by the French, who were the first in Europe to market certified Label Rouge chickens in the 1960s, based on slow-growing regional breeds. Birds are reared extensively in outdoor areas until at least 81 days of age and receive feeds containing natural components according to a strict diet formula. It is estimated that over $30 \%$ of broiler chickens sold on the French market are reared under the Label Rouge system and this success is based on traditional farming practices combined with caring for bird welfare and quality of the end product (Fanatico et al., 2006).

Similar to other European countries, Polish consumers are increasingly interested in extensively produced food, all the more so because Poland has a large (19 lines) and valuable collection of laying hens enrolled in the genetic resources conservation programme and located in several farms all over the country. Most of the flocks were included by FAO in the list of the world genetic resources that need to be conserved (World Watch List, FAO, 2000). Native and locally adapted breeds of hens are closely linked to the tradition and culture of rural communities. Research to date has shown these hen breeds to vary in phenotype, productivity, and biological quality of hatching eggs and meat. The colourfully feathered birds are a fine sight in rural backyards. Making efficient use of poor meadows and pastures as well as wasteland, they provide eggs and meat with good taste and dietetic qualities (Krawczyk, 2009). Recent years have witnessed a considerable interest in Greenleg and Yellowleg Partridge breeds as well as heavier lines of Rhode Island Red, Sussex, New Hampshire and Barred Rock hens. In the future, they may provide the material for producing general-purpose hens valued for both laying performance and dressing percentage. Hybrid hens derived from crossing traditional Polish breeds (Yellowleg Partridge, Rhode Island Red or Sussex) and roosters from Hubbard parent stock can be raised beyond 81 days to obtain higher body weights with desired structure and sensory properties of meat that live up to consumer expectations (Połtowicz, 2007; Połtowicz and Doktor, 2012). Koreleski et al. (2008), who sought to find slow-growing chickens for extensive management, concluded that the optimum period of raising WJ44 and N-11 hybrids is 12 weeks. In addition, hens of heavy breeds (Rhode Island Red, New Hampshire or Barred Rock) tested at 56 days of age are characterized by good muscling and dressing percentage, and are ideally suited for stewing. Meat from Greenleg Partridge and Rhode Island Red hens contains less fat and cholesterol 
compared to other lines (Puchała et al., 2014). The results show that the hen populations conserved for biodiversity differ in body weight and carcass colour and provide material for finding dual-purpose hens to be used for egg and meat. In addition, a significant problem in using hens for both egg and meat production is that the number of unwanted cockerels increases with increasing intensity of egg production. This problem can be overcome by castration and fattening of cockerels, all the more so because there is a recurring interest in different old Polish cuisine dishes, which were based on broth, and the capons of general-purpose breeds were used to prepare exquisite dishes. Also the website of the Polish Ministry of Agriculture and Rural Development contains information about the Old Polish Capon (Kapton staropolski), which was included in the List of Traditional Products in 2010. Old recipes from the "Compendium Ferculorum" are coming back in traditional or modern style, while international culinary organizations (Slow Food, Euro-Toques) became involved in the promotion of Polish capons.

The aim of this paper was to review the literature on capon production, including the effects of castration on the bird's body and on the quality of meat obtained.

\section{Castration from a historical and contemporary perspective}

The term capon comes from ancient Rome and refers to a castrated and specially fattened rooster. The castration (caponization) procedure was used long before Christ in China, Greece and Rome. In Europe, caponization was first associated with a religious ritual and making offerings to the gods. Historical sources report that they were offered to the gods, among others on the Greek island of Delos in the 7th century BC. In Rome, this procedure was performed to increase the body weight of roosters as a reaction to Lex Faunia, which was passed by the Roman Senate in 162 BC to save on food; fattening of capons proved to be a highly effective method for obtaining meat raw material (Toussaint-Samat, 2009). The advantages of this meat were noticed much later when capon meat turned out to be juicier and more tender than meat from a regular rooster (Sirri et al., 2009). In the Middle Ages caponization was popular in France and Italy, and the culinary use of capons was described in many recipes. In Poland, the tradition of capon production dates back to the 16th century, and capon meat was a status symbol on royal and noble tables. It was used to make excellent roasts, tasty and aromatic broths, and gravies. Capon meat has the place of honour in the first cookbook written by Stanisław Czerniecki, "Compendium Ferculorum or a Collection of Dishes", published in 1682 in Kraków (Dumanowski et al., 2010).

In the 1950s, Szuman (1951) distinguished three methods of bird castration: empirical (digital or Slavic), instrumental (American), and hormonal, which raised serious concerns and was banned in some countries. The literature also reported the use of castration procedure in ducks, geese, turkeys and ostriches, but it was not as frequent as in roosters (Hobday, 1914).

In Poland, caponization was practised until after World War II. As a result of the political changes, capons disappeared for some time from farms and menus, because they were treated as a relic of the past. A ban on the castration of roosters was introduced soon afterwards, which caused the production to cease. The regulations changed in 2008 and the producers have shown increasing interest in fattening of 
capons since then. According to the Commission Regulation No 543/2008 of 16 June 2008, "a capon is a male fowl castrated surgically before reaching sexual maturity and slaughtered at a minimum age of 140 days: after castration the capons must be fattened for at least 77 days".

Today, roosters are castrated surgically in China, Japan, the USA, Taiwan, and France, which leads the way in capon production and consumption (Symeon et al., 2010). In Italy, capons are produced seasonally with the highest demand observed during Christmas (Sirri et al., 2009). In the past, capons were produced using heavier breeds, which were raised to maximize body weight (4 to $6 \mathrm{~kg}$ ) and showed high carcass fatness (Mast et al., 1981). At present, capon production makes increasing use of native, slow-growing breeds specific to a country or region: the Bresse breed in France, Castellana Negra in Spain, Hinai-Jidori in Japan, and Jersey Giant, Brahms Plymouth Rocks and Cochin in the USA. Native breeds (Greenleg Partridge, Yellowleg Partridge) or locally adapted breeds (Rhode Island Red, Sussex, Barred Rock) are also most frequently used in Poland. Immunocastration is also used in the United States. It involves the use of female hormones to suppress the male sex hormone testosterone, but research has shown the quality of meat from surgically castrated cockerels to be superior (Rahman et al., 2004). Caponization is not allowed in Great Britain on humanitarian grounds.

\section{Castration procedure and its effects on birds}

Unlike in most mammals avian testes are located within the body cavity, as a result of which castration is more difficult to perform. Rooster gonads are usually bean-shaped, cream or cream-grey in colour, and may be pigmented. Held on short mesenteries in the dorsal body cavity, they are located symmetrically on each side of the spinal cord, wedged between the kidney and the aorta. Testicular size depends on the species, breed, age, physiological status and individual characteristics of males, with the left testis being larger than the right (Gogolewski and Czerwiński, 2012). At present, castration in Poland is performed under strict supervision of a veterinary doctor, using the principles of antiseptic surgery. The surgery is performed under general or local anaesthesia, usually by two persons using basic surgical instruments (scalpel, tweezers, wound spreader, seizing forceps, absorbable surgical suture, and others). Feathers are removed on both sides of the ribs, the operative field is disinfected, and the bird is anaesthetized. The incision line, about $3-4 \mathrm{~cm}$ in length, should be made along the anterior border of the last rib. Next, the intestine is delicately moved away and the testis is carefully removed with special forceps. This procedure is generally performed on both sides of the chest, but one incision is also possible. Depending on the operator's preference, the wound can be stitched or left open to heal (Jacob and Mather, 2000). The authors provide a detailed description of the procedure and note that the birds should be adequately prepared by withdrawing feed for 24 hours and water for several hours before the surgery. Feed withdrawal facilitates the procedure and produces lower mortality rates caused by intraoperative complications, because reduced gut fill facilitates access to reproductive organs and lowers the incidence of bleeding when they are removed (Rikimaru et al., 2009). Surgical removal of the testes in male birds can be performed at any age but preferably between 6 and 14 weeks, 
with the date being dependent on the breed and body weight, which should be around $0.5 \mathrm{~kg}$ at surgery. Therefore, heavier, fast-growing breeds should be operated several weeks earlier than lighter, slow-growing breeds (around 3 to 3.5 months). In general, caponizing losses are estimated to range between 5 and 20\% (Rikimaru et al., 2011). Gogolewski and Czerwiński (2012) report that mortality in older birds may reach $50 \%$, because this procedure is more time-consuming and difficult to perform, and regeneration of the testes occurs more frequently. After the surgery, males are moved to a clean facility, provided with feed and water, and administered an antibiotic for 5 days to reduce bacterial infections. In general, the procedure and the wound healing period are well tolerated by the birds. The most common complication is the wind puff, which is caused by air escaping from the body cavity into the subcutaneous tissue. Puncturing it twice or three times will release the air.

Following the castration and deficiency of testosterone, the levels of which are low but still detectable (Shao et al., 2009; Symeon et al., 2010; Lin et al., 2012), males soon show changes in appearance and behaviour (Chen et al., 2006). Birds become more docile and less active, do not crow, and are unwilling to mate. The comb and wattle are turning pale and flaccid, and regress in a few weeks. Energy that is normally expended in fighting and territorial protection is greatly reduced, allowing more efficient conversion of feed, fat deposition and improved meat quality (Jacob and Mather, 2000). In castrated cockerels, Rahman et al. (2004) found significantly lower red blood cell counts, hemoglobin concentrations and hematocrit values, which was also observed by Mahmud et al. (2013) and Kasperek et al. (2013). Chen et al. (2006) found testosterone concentration to be negatively correlated with fat deposition. The same authors also reported higher cholesterol and triglyceride concentrations in castrated roosters, which is associated with increased hepatic lipogenesis as a result of the surgical removal of the testes.

The castration procedure must be performed with high precision, because failure to remove single testicular cells will cause the organ to regenerate and resume sex hormone production, which can be observed in the appearance (regrowth of the comb and wattle) and behaviour of the birds (increased activity and aggression). Sirri et al. (2009) report that normally around $10 \%$ of the birds are slips and their meat quality parameters fall between those of capons and roosters.

\section{Nutritional and environmental requirements for raising capons}

Capons are fattened for at least 11 weeks and the slaughter depends on the breed, which determines the body weight. Most often, however, it is carried out much later at 8 or even 10 months of age. Nutrition plays an essential role in capon production. Feeding is generally recommended to be divided into $2-3$ periods, with $70 \%$ of the diet formed by cereals supplemented with roughages. Lin and Hsu (2002) proposed two types of mixtures in the feeding of native cockerels: one containing 19\% protein and $3000(\mathrm{kcal} / \mathrm{kg})$ metabolizable energy (ME) until 18 weeks, and another containing $17 \%$ protein and $2800 \mathrm{kcal} / \mathrm{kg}$ ME from 19 to 28 weeks. In a study by Muriel Duran (2004), the dietary protein and ME content $(23.5 \%$ and $3100 \mathrm{kcal} / \mathrm{kg}$, respectively) was decreased to $18 \%$ and $2900 \mathrm{kcal} / \mathrm{kg}$, respectively, several weeks before the slaughter. In fact, the final feeding (2-3 weeks before slaughter) was in- 
dicated centuries ago. During this period birds were subjected to special fattening with dumplings from barley or oat meal, milk, honey and herbs. Today, especially small farms promote the use of a white diet based on milk products, namely bread soaked in milk, curd cheese, and whey. Allowing birds access to the free range is particularly important, and the required stocking rate and area of open-air runs are specified by the Commission Regulation (EC) No 543/2008. In principle, free-range capons should have access to open-air runs with an area of not less than $2 \mathrm{~m}^{2} / \mathrm{bird}$ during at least half their lifetime. The stocking rate in the house should not exceed 7.5 birds $/ \mathrm{m}^{2}$, and not more than $27.5 \mathrm{~kg}$ live weight $/ \mathrm{m}^{2}$. In traditional free range, indoor stocking density per $\mathrm{m}^{2}$ must not exceed 12 birds until 91 days of age, and 6.25 birds (not more than $35 \mathrm{~kg}$ live weight) later on. Capons should have continuous daytime access to open-air runs at least from the age of six weeks, with the open-air runs comprising an area of at least $2 \mathrm{~m}^{2}$ for birds aged 91 days and $4 \mathrm{~m}^{2}$ /bird until the end of fattening. Total usable area of poultry houses should not exceed $1600 \mathrm{~m}^{2}$, and each poultry house should not contain more than 2500 capons. The poultry house should be provided with popholes of a combined length at least equal to $4 \mathrm{~m}$ per $100 \mathrm{~m}^{2}$ surface of the house. In extensive barn systems, the stocking rate per $\mathrm{m}^{2}$ floor space should not exceed $15 \mathrm{birds} / \mathrm{m}^{2}$, and not more than $25 \mathrm{~kg}$ live weight.

\section{Effect of rooster castration on body weight and meat quality}

The advantages of rooster castration have been known for a long time. Sterilized birds are characterized by higher weight gains and better feed conversion, and their final body weight is 10-20\% higher compared to intact roosters (Mast et al., 1981; Lin and Hsu, 2002; Rahman et al., 2004; Mahmud et al., 2013). However, Miguel et al. (2008) and Shao et al. (2009) did not observe an increase in the body weight of caponized roosters. These inconsistent results might be attributable to differences in breed/genotype, castration age, feeding level, rearing conditions, and slaughter age of the compared birds. In a study by Tor et al. (2002), caponizing was found to have a beneficial effect on increasing the weight of breast muscles (265.1 vs $347.9 \mathrm{~g}$ ) and leg muscles (267.1 vs $305.2 \mathrm{~g}$ ). Furthermore, depending on the breed and slaughter age of the capons, deposition of adipose tissue in the abdominal cavity and of subcutaneous fat was found to increase significantly (even by a factor of 2-4), which made the meat more delicate, juicy and tender (Cheng and Hsu, 2002; Hsu and Lin, 2003; Tor et al., 2005; Chen et al., 2006; Sirri et al., 2009; Sinanoglou et al., 2011). Caponization was also reported to have an effect on carcass and meat colour (Sirri et al., 2009). Compared to uncastrated roosters, the carcasses of capons were characterized by higher lightness $\left(\mathrm{L}^{*}=55.78 \mathrm{vs} \mathrm{L}^{*}=50.80\right)$ and yellowness $\left(\mathrm{b}^{*}=11.91 \mathrm{vs}\right.$ $\left.\mathrm{b}^{*}=8.41\right)$ values and lower redness $\left(\mathrm{a}^{*}=4.22\right.$ vs a*=5.61). Similar relationships were also found for $\mathrm{L}^{*} \mathrm{a} \mathrm{b}^{*}$ colour of breast and leg muscles, with statistically significant differences $(\mathrm{P}<0.05)$. Castrated birds also exhibit higher weights of the internal organs, in particular the liver, gizzard and intestine (Rahman et al., 2004). A different tendency was observed for heart weight (Symeon et al., 2010). Studies by Lin and Hsu (2002) and Miguel et al. (2008) showed that caponization has no significant effect on $\mathrm{pH} 24$ hours postmortem and thermal loss due to cooking, although tenderness was superior to that in intact roosters. 
Research on the possibility of using breeds conserved for biodiversity for capon production has been also conducted in Poland (Calik et al., 2013). The results obtained indicate that the caponization of Greenleg Partridge (Z-11) cockerels had a beneficial effect on increasing the final body weight (by $241 \mathrm{~g}$ ) and dressing percentage with giblets (71.66 vs $73.07 \%$ ) and without giblets (67.37 vs $69.17 \%$ ). A similar tendency was observed for the content of breast muscles (16.06 vs $17.28 \%)$ and leg muscles in carcass $(20.34$ vs $21.81 \%)(\mathrm{P}<0.05)$. This shows that the breed can be used for capon production and the procedure can be applied in practice on a wider scale, especially since there has been an increasing interest in the fattening of capons over recent years, as evidenced by the establishment of the first capon producers cooperative, following the example of France.

\section{Conclusions}

In summing up it is concluded that capon production could be an alternative sector of poultry production with particular use of native or locally adapted breeds. The primary purpose will be to produce high quality meat with valuable sensory attributes. In addition, the castration procedure may help put surplus cockerels to use, which also has an economic dimension.

\section{References}

Berri C., Le Bihan-Duval E., B à̀za E., Chartrin P., Picgirard L., Jehl N., Quent in M., P i c ard M., D u cl o s J. (2005). Further processing characteristics of breast and leg meat from fast-, medium- and slow-growing commercial chickens. Anim. Res., 54: 123-134.

Calik J., Połtow i c z K., Św iąt k i e w i c z S., P i e tras M. (2013). Effect of caponization on the body weight and dressing percentage of Greenleg Partridge cocks (in Polish). Proc. Pol-Ger. Conf., Balice, Poland, 15-17.10.2013, pp. 223-224.

Chen K.L., Hsieh T.Y., Chiou P.W.S. (2006). Caponization effects on growth performance and lipid metabolism in Taiwan country chicken cockerels. Asian-Aust. J. Anim. Sci., 19: 438-443.

$\mathrm{C}$ h e $\mathrm{n} g$ L.Y., H s u J.C. (2002). Effects of surgical caponization on growth performance, fibre diameter and some physical properties of muscles in Taiwan country chicken cockerels. Asian J. Anim. Sci., 15: 401-405.

Commission Regulation (EC) No 543/2008 of 16 June 2008 laying down detailed rules for the application of Council Regulation (EC) No 1234/2007 as regards the marketing standards for poultry meat.

Debut M., Berri C., Arnould C., Guemené D., Santé-Lhoutellier V., Sellier N., Baéza E., Jehl N., Jég o Y., B e a umont C., Le Bihan-Duval E. (2007). Behavioral and physiological responses of three chicken breeds to pre-slaughter shackling and acute heat stress. Brit. Poultry Sci., 46: 527-535.

Dumanowski J., Pawlas A., Poznański J. (2010). Stanisław Czerniecki's culinary secrets. Recipes from the oldest Polish cookbook, dating back to 1682 (in Polish). Muzeum-Pałac w Wilanowie, Warszawa, 143 pp.

Fanatico A.C., Pilla i P.B., Cavitt L.C., Emmert J.L, Meullenet J.F., Owens C.M. (2006). Evaluation of slower-growing broiler genotypes grown with and without outdoor access: sensory attributes. Poultry Sci., 85: 337-343.

Gil ew sk i R., Ja n o ch a A., To m c zy k G., W ęży k S. (2010). New trends in chicken breeding and production (in Polish). Oficyna Wydawnicza Hoża, Warszawa, 219 pp.

G og o le w sk i L., C z erw iński M. (2012). Caponizing roosters (in Polish). Pol. Drob., 1: 46-48.

Ho b d a y F.T.G. (1914). Castration (including cryptorchidism and caponing) and ovariotomy. Johnston, London, 2nd ed., 88 pp. 
H s u J.C., L in C.Y. (2003). Influence of caponization on the carcass characteristics in Taiwan country chicken cockerels. Asian-Aust. J. Anim. Sci., 16: 575-580.

J a c o b J., M a the r F.B. (2000). Capons. Factsheet PS-54, Department of Animal Sciences, Florida Cooperative Extension Service, Institute of Food and Agricultural Sciences, University of Florida, Gainesville. www.edis.ufl.edu.

Kasperek K., Kwi ecień M., Grela E., Pałyszka M., Knaga S., Jeżewska-Witkowska G. (2013). The Greenleg Partridge rooster caponing influence on selected blood parameters. Proc. XXV Int. Poult. Symp. PB WPSA, Zegrze k. Warszawy, 2-4.09.2013, pp. 51-55.

K or eleski J., Św ią tki ew i c z S., A r c zew sk a A. (2008). Dual-purpose slow-growing chickens for meat production. Ann. Anim. Sci., 8: 281-287.

K r a w c z y k J. (2009). Quality of eggs from Polish native Greenleg Partridge chicken-hens maintained in organic vs. backyard production systems. Anim. Sci. Pap. Rep., 27: 227-235

L in C.Y., H s u J.C. (2002). Effects of surgical caponization on growth performance, fiber diameter and some physical properties of muscles in Taiwan country chicken cockerels. Asian-Aust. J. Anim. Sci., 15: 401-405.

L in C.Y., H s u J.C., Wa n T.C (2012). Effect of age and caponization on blood parameters and bone development of male native chickens in Taiwan. Asian-Aust. J. Anim. Sci., 25: 994-1002.

Mahmud M.A., Shaba P., Gana J., Yis a H.Y., Ndagimba R. (2013). Effects of surgical caponisation on growth, carcass and some hematological parameters in cockerel chickens. Sok. J. Vet. Sci., 11: 57-62.

Mas t M.G., Jordan H.C., Macneil J.H. (1981). The effect of partial and complete caponization on growth rate, yield, and selected physical and sensory attributes of cockerels. Poultry Sci., 60: 1827-1833.

Migu el J.A., Ciri a J., A s e n j o B., C a lv o J.L. (2008). Effect of caponisation on growth and on carcass and meat characteristics in Castellana Negra native Spanish chickens. Animal, 2: 305-311.

Muriel Duran A. (2004). The effect of caponization on production indices and carcass and meat characteristic in free-range Extremena Azul chickens. Span. J. Agric. Res., 2: 211-216.

P o ł t o w i c z K. (2007). Effect of crossing slow-growing hens with Hubbard cocks on performance and meat quality of the crossbreds. Proc. XVIII European Symposium on the Quality of Poultry Meat, Prague, Czech Republic, 2-5.09.2007, pp. 297-300.

P ołt ow i c z K., D o k t o r J. (2012). Effect of slaughter age on performance and meat quality of slowgrowing broiler chickens. Ann. Anim. Sci., 12: 621-631.

Puchała M., Kraw c z y k J., Ca lik J. (2014). Influence of origin of laying hens on the quality of their carcasses and meat after the first laying period. Ann. Anim. Sci., 14: 685-696.

R a h m a n M.M., I s 1 a m M.A., A 1 i M.Y., K ho n d a k e r M.E.A., H o s s a in M.M. (2004). Effect of caponization on body weight, hematological traits and blood cholesterol concentration of Nara chicken. Int. J. Poultry Sci., 3: 284-286.

Rikimaru K., Yas uda M., Komats u M., Is hizuka J. (2009). Effects of caponization on growth performance and carcass traits in Hinai-jidori chicken. Jpn. Poultry Sci., 46: 351-355.

Riki maru K., Tak ah a s hi H., N i chlos M.A. (2011). An efficient method of early caponization in slow-growing meat-type chickens. Poultry Sci., 90: 1852-1857.

S h a o Y., Wu CH., Li J. Zh a o Ch. (2009). The effects of different caponization age on growth performance and blood parameters in male Tibetan chicken. Asian J. Anim. Vet. Adv., 4: 228-236.

Sinanoglou V.J., Mant is F., Miniadis-Meimaroglou S., Symeon G.K., Bize1 is I.A. (2011). Effects of caponisation on lipid and fatty acid composition of intramuscular and abdominal fat of medium-growth broilers. Brit. Poultry Sci., 52: 310-317.

Sirri F., Bianchi M., Petracci M., Meluzzi A. (2009). Influence of partial and complete caponization on chicken meat quality. Poultry Sci., 88: 1466-1473.

Symeon G.K., Mant is F., Bizelis I., Kominakis A., Rogdak is E. (2010). Effects of caponization on growth performance, carcass composition, and meat quality of medium growth broiler. Poultry Sci., 89: 1481-1489.

S z u m a n J. (1951). Poultry Breeding (in Polish). PWRiL Warszawa, 594 pp.

Świerczewska E., S i ennicka A., Michalczuk M. (2002). Changes in performance and anatomo-physiological traits of poultry in response to selection (in Polish). Zesz. Nauk. PTZ, 66: $63-72$. 
Tor M., Estany J., Villa lba D., Molina E., Cubilò D. (2002). Comparison of carcass composition by parts and tissues between cocks and capons. Anim. Res., 51: 421-43.

Tor M., Estany J., Francesch D.A., Cubilò D. (2005). Comparison of fatty acid profiles of edible meat, adipose tissues and muscles between cocks and capons. Anim. Res., 54: 413-424.

Tous saint-S a mat M. (2009). A History of Food. Wiley-Blackwell (John Wiley \& Sons Ltd.), Chichester, 2nd ed., 733 pp.

World Watch List for Domestic Animal Diversity (2000). FAO/UNEP, Roma, 3rd ed.

www.minrol.gov.pl/pol/jakosc-zywnosci/produkty-regionalne-i-tradycyjne/lista-produktow-tradycyjnych.

Received: 13 III 2014

Accepted: 13 V 2014 